\title{
MUSEO DARK-NET Acumulación y circulación de arte
}

\author{
Dark-Net Museum \\ Accumulation and Circulation of Art
}

Florencia Avellaneda I florencialarumbe@gmail.com

Facultad de Bellas Artes. Universidad Nacional de La Plata. Argentina

Reseña a Hito Steyerel (2018). Arte Duty Free: el arte en la era de la guerra civil planetaria. Ciudad Autónoma de Buenos Aires, Argentina:

Caja Negra. 286 páginas

Recibido: 19/12/2018

Aceptado: 3/4/2019

\section{RESUMEN}

En Arte Duty Free: el arte en la era de la guerra civil planetaria (2018), Hito Steyerel nos invita a reflexionar sobre un nuevo escenario global caracterizado por una guerra civil planetaria plagada de nuevas prácticas y saberes que se escapan al ojo humano. Como producto de esto, comienzan a desplegarse nuevas formas de pensar las imágenes y su circulación, el arte y los museos. A su vez, se produce un cambio en la noción tradicional de museo localizado en un estado-nación que ha de desplegarse sobre espacios offshore, dentro de un paisaje oscuro, sin fronteras y libre de impuestos, un museo al estilo dark-net.

\section{PALABRAS CLAVE}

Historia; museo; arte; tecnología; almacenamiento

\begin{abstract}
In Art Duty Free: art in the era of planetary civil war (2018), Hito Steyerel, invites us to think in a new global scenario characterized by a planetary civil war plagued by new practices and knowledge that escape the human eye. As a result of this, new ways of contemplating the images and their circulation, art and museums begin to unfold. In turn, there is a shift in the traditional notion of a museum located in a nation-state that unfolds over offshore spaces, within a dark, borderless and tax-free landscape, a dark-net-style museum.
\end{abstract}

\section{KEYWORDS}

History; museum; art; technology; storage 
Hito Steyerel es una artista y ensayista nacida en Munich, Alemania, en 1966. Es doctora en Filosofía por la Universidad de Viena y profesora en el New Art Media en la Universidad de Berlín. Actualmente, se dedica al campo de los medios de comunicación y al análisis de la circulación masiva de imágenes. Sus estudios se orientan a temas como el feminismo, la violencia política y las tecnologías digitales, temáticas que aborda mediante el uso de la ironía y la apropiación de materiales visuales y textuales. Esta primera edición lleva el mismo título que la retrospectiva de su obra exhibida en el Museo Reina Sofía de Madrid en 2015-2016 y pertenece a la colección Futuros Próximos de la Editorial Caja Negra. Esta colección engloba una serie estudios relacionados con la crítica cultural, las transformaciones del tiempo presente y la comprensión contemporánea de temáticas como la estética, la política y los estudios sobre tecnología.

Los quince capítulos que contiene este libro plantean un recorrido tan diverso como interconectado entre sí, por una lógica que pretende revelar las ruinas de una sociedad en desequilibrio. Con perspicacia, la autora despliega, a través de complejas relaciones y afirmaciones, una mirada sobre el pasado y el presente construida a partir de un relato que connota la euforia de una efervescente industria tecnológica armamentista, que ha llegado a ocupar casi por completo el entramado sociocultural de consumo, circulación y producción de arte. De este modo, el relato se consuma a partir de un enrevesado pero acertado juego entre pesimismo, ironía y ficcionalidad.

En el primer capítulo, la autora da inicio a su relato con un acontecimiento en particular: un tanque de batalla soviético (IS3, losif Stalin) fue readaptado por un grupo separatista pro ruso al este de Ucrania. Antes de ser reutilizado, el artefacto cumplía la función de ser un bien conmemorativo, es decir, un patrimonio tangible de la Segunda Guerra Mundial, el cual se encontraba emplazado sobre un exhibidor histórico. Concretamente, Steyerel, cuestiona si la función de dicho objeto caduca una vez que es exhibido o si el exhibidor funciona, en este caso, como un depósito temporario para la guerra. $Y$, en tal caso, ¿es el museo, como institución, un garaje de objetos históricos?, ¿cómo podríamos pensar a las instituciones artísticas en una época definida por la guerra civil planetaria, la creciente inequidad y la tecnología digital propietaria? En este aspecto, ¿cuál es la función de la historia? En respuesta a esta última pregunta, la autora considera que la base sobre la que se sustenta y se nutre la historia se encuentra bajo el origen de dominios imaginarios. Así, la historia cambia de rostro, es un combatiente irregular, que actúa, simula y continúa modificándose.

En algún momento, internet fue un gran faro de esperanza que traía consigo nuevas expectativas. Sin embargo, el desarrollo cada vez más voraz de la industria de la guerra permeó en la subjetividad de aquellos que cayeron en el engaño de series completas de algoritmos y spam, repetidos una y otra vez. La historia y la vida misma parecen haberse convertido en un loop cifrado, que íntimamente se apodera de lo hipercontemporáneo actuando, simulando y modificándose. Como postula Steyerel, entramos en un periodo de disrupción creativa, donde el horizonte de entendimiento común es reemplazado por historias artificiales, estrechas, paralelas, verticales, recortadas y sesgadas. El tiempo ha sido dado vuelta y avanza hacia atrás, caracterizado por un incremento de máquinas automatizadas y una creciente fragmentación política.

Ejércitos de bots recolectan información de redes sociales como Twitter y Facebook para crear perfiles falsos y hacer campaña política. Esta utilización de la tecnología para el uso político, también incluye a gobiernos que crean imágenes secretas (conjuntos de datos desalineados y llenos de ruido) imposibles de ser comprendidas por el ojo humano. En este contexto, el arte contemporáneo se convierte en un ejecutor para la comunidad global.

El papel del museo, como institución que alberga historia, se ve impregnado de stasis. En su interior cobija una guerra civil irresuelta que no concluye 
jamás, donde el conflicto no es un medio para llegar a una resolución, sino todo lo contrario, un medio para prolongar una eterna y conflictiva agonía. En este escenario, el arte es consumido por señores de la guerra y por corporaciones que, luego de adquirirlo, lo depositan en zonas libres de impuestos (arte duty free). De modo que, con mayor frecuencia, el acceso del público para contemplar obras de arte se transforma en algo impensable.

Para la autora, la esperanza es el Caballo de Troya del engaño y la explotación. Es también el elemento conductor de toda búsqueda de cambio. Nos encontramos arrojados en una época donde las obras de arte permanecen embaladas como figurillas de acción que conservan su valor si no son abiertas. Los objetos-arte cruzan fronteras y naciones sin ser vistas en espacios offshore. Son almacenadas en un museo de la era de internet, o más bien museo darknet, cuyo movimiento es oscuro y el paisaje es poco claro.

Sin ir más lejos, Steyerel nos coloca dentro de un nuevo paradigma planetario, cargado de nuevos interrogantes y problemáticas las cuales no podemos evadir. Ha llegado el momento de la era digital, de la industria armamentista y el arte en la era de la guerra civil planetaria. No nos dejemos engañar, accionemos críticamente. 